\title{
Censura y edición póstuma de la obra de Hipólita de Rocabertí: a propósito de unos poemas manipulados
}

\section{Censorship and posthumous edition of the work of Hipólita de Rocabertí: concerning some manipulated poems}

\author{
VERÒNICA ZARAGOZA GÓMEZ \\ veronica.zarago@gmail.com \\ Universitat Oberta de Catalunya
}

\begin{abstract}
Resumen: El objeto de este trabajo es ahondar en algunos fenómenos del proceso de publicación de la obra de la dominica catalana Hipólita de Rocabertí (Peralada, 1553-Barcelona, 1624), desde un acercamiento filológico inédito, a través del análisis y la edición de tres de sus poemas, que fueron impresos en el Tratado dividido en quatro libros. El primero contiene: la exposición literal y mística de los psalmos penitenciales; el segundo, la preparación para la muerte; el tercero, coloquios del alma christiana con Dios; el quarto, fundamento sólido de la oración por ser todo fundado en el santo Evangelio (Valencia, Jaime de Bordázar, 1683), y que presentan una transmisión textual peculiar, puesto que algunos de ellos fueron modificados en distintas emisiones del testimonio. A través del cotejo y la colación de las variantes de los diferentes testimonios de estas composiciones que editamos, pretendemos aportar nuevos materiales interpretativos que permitan dilucidar mejor el proceso de construcción de la imagen de santidad de la autora operado en el siglo XVII, a través de la edición póstuma de sus obras, en el nuevo marco de la reforma católica post-tridentina.
\end{abstract}

Palabras clave: Hipólita de Rocabertí; poesía conventual; literatura femenina de la edad moderna; santidad femenina; edición y crítica textual

\begin{abstract}
The goal of this paper is to examine certain aspects of the publishing process of the work of the Catalan Dominican nun Hipólita de Rocabertí from an original philological perspective through the edition and analysis of three of her poems, which were published in the Tratado dividido en quatro libros. El primero contiene: la exposición literal y mistica de los psalmos penitenciales; el segundo, la preparación para la muerte; el tercero, coloquios del alma christiana con Dios; el quarto, fundamento sólido de la oración por ser todo fundado en el santo Evangelio (Valencia, Jaime de Bordázar, 1683) and which present a complex textual transmission, given that some of them were modified in various editions. By comparing the different testimonies of the compositions that we edit, we intend to provide new interpretative materials, which might contribute to a better understanding of the building process of the image of the author's holiness in the XVII century, in the new framework of the post-tridentine catholic reform.
\end{abstract}

Keywords: Hipólita de Rocabertí; conventual poetry; women's literature in the modern age; female holiness; textual criticism and edition 
Verònica Zaragoza Gómez. Censura y edición póstuma de la obra de Hipólita de Rocabertí: a propósito de unos poemas manipulados

\section{Introducción}

A tenor de lo que se ha ido publicando en los últimos años, Isabel de Rocabertí y Soler (Peralada, 1553-Barcelona, 1624) -más conocida como Hipólita de Jesús Rocabertí, su nombre de profesiónes, hoy por hoy, una de las figuras religiosas femeninas más estudiadas de la época moderna, después de haber permanecido durante algunos siglos en la penumbra. ${ }^{1}$ En líneas generales, debemos recordar que Hipólita vivió sus días y ejerció de maestra de novicias durante treinta años en el convento dominico de Nuestra Señora de los Ángeles de Barcelona, llegando a detentar también el cargo de supriora. En aquel claustro, donde había ingresado a la corta edad de diez años, dedicaría su apacible vida al estudio y a una ingente labor de escritura alternada con la oración, al servicio del nuevo clima reformista que se estaba gestando (no en vano, es conocida por las prédicas y charlas que dedicó a novicias y a profesas de distintas órdenes, ${ }^{2}$ además de ser enviada al convento agustino de Santa María Magdalena de la misma ciudad de Barcelona, donde durante cinco años ejercería de maestra reformadora de la observancia).

Hay que mencionar además que, después de una vida marcada por las experiencias místicas y los dones carismáticos, y tras morir en opinión de santidad a los 73 años de edad, en 1674 se incoó el proceso ordinario sobre su causa de beatificación en Roma, alentado por su sobrino, fray Juan Tomás de Rocabertí y Safortesa (Peralada, 1627-Madrid, 1699). ${ }^{3}$ Efectivamente, el que llegaría a ser arzobispo de Valencia, desde 1676, y más tarde, inquisidor general y maestro general de predicadores, invirtió muchos esfuerzos a fin de confirmar públicamente la santidad de su tía paterna y a elevar su reputación hacia los altares: para promover dicho proceso, después de iniciar el trasiego informativo sobre la vida, virtudes y santidad de sor Hipólita, asumió la impresión y revisión de todas las obras que esta había dejado en el convento y que, tras un examen riguroso de su ortodoxia, debían ser prueba irrefutable de su santidad. La suma de los tratados espirituales y exegéticos que vieron la luz póstumamente, asciende en torno a los 26 volúmenes, cuya edición le fue encomendada al también dominico fray Antonio de Lorea (Almagro, 1635-Valencia, 1687). Al mismo tiempo, fueron publicadas las hagiografías que hoy conocemos de la religiosa: el Breve ristretto della vita maravigliosa e delle virtú mirabili della venerabile madre e serva di Dio Suor Ippolita di Giesu... publicado en Roma, en 1672, y la biografía

\footnotetext{
*Agradecemos la lectura atenta y revisiones de Eulalia Miralles, Albert Rossich y Pep Valsalobre para la mejora del trabajo. Este estudio se enmarca en el proyecto de investigación FFI2012-37140. Advertimos que en la transcripción de los textos se ha respetado la ortografía del modelo excepto en la puntuación, accentuación y el uso de mayúsculas y minúsculas, para lo que seguimos los criterios actuales. Para la edición de los poemas, nos basamos en los criterios generales establecidos por Blecua \& Serés (dir. 2008)

1 Véase el estudio biográfico de Eulàlia d'Ahumada (2013), basado en un riguroso trabajo de documentación bibliográfica y en la consulta del archivo conventual.

2 En cuanto al discurso reformista de sor Hipólita dedicado a las monjas del convento de los Ángeles: Zaragoza (2012 [2015]: 243-247).

3 Véase el exhaustivo trabajo biográfico de Callado (2007 y 2012).
}

SCRIPTA, Revista internacional de literatura i cultura medieval i moderna, núm. 8 / desembre 2016 / pp. 194-223 ISSN: 2340-4841 · doi:10.7203/SCRIPTA.8.9295 
del propio Lorea, inspirada en la anterior, publicada en Valencia (Lorea 1679) que, con marcado tono encomiástico, se sumaban a la campaña de promoción del modelo femenino espiritual y erudito de sor Hipólita. Una causa que, pese al cuidadoso celo y a los esfuerzos del arzobispo de Valencia, ${ }^{4}$ se vería truncada por las coyunturas sociopolíticas nefastas del momento, asociadas especialmente con la condena teológica del quietismo como herejía doctrinal y con la campaña de control de la santidad y censura de textos místicos por parte de la Congregación romana, que supuso la inclusión de algunas obras de sor Hipólita en el Index librorum probibitorum desde 1687, empezando por el Libro primero De su admirable vida y dotrina, que escrivo de su mano publicado en 1679 (Malena 2003: esp. 250 y ss.). De hecho, entre las razones que explicarían el fracaso de este proceso de santidad, Rosa M. Alabrús aduce a la «presión de los jesuitas en su contra, las dudas y vacilaciones de los propios dominicos y algunos poderes fácticos en Roma hostiles, con el estigma del iluminismo quietista flotando» (Alabrús 2015a: 243); lo que contribuyó a proyectar sobre la religiosa el áurea de «personaje historiográficamente desubicado: ni ortodoxo ni heterodoxo» (Giordano 2012b: 208).

Sea como fuere, Hipólita de Jesús ha adquirido, en los últimos años, una gran importancia en el campo de la historiografía religiosa y literaria, cual otra Teresa de Jesús. Bien por su carisma de santidad, bien por su faceta de escritora espiritual, lo cierto es que su descomunal prosa (auto) biográfica, espiritual y devocional sigue interesando a la crítica, que la está diseccionando y analizando desde sus múltiples facetas (sin ánimo de exhaustividad: Ahumada 2011; Giordano 2011, 2012a y 2012b; Lavrin 2014; Alabrús 2015a y 2015b; Poutrin 2015). Así pues, el volumen colosal de obras de nuestra dominica revela que se trata de una de las autoras más prolíficas del ámbito hispánico moderno hasta el punto que su biógrafo, Antonio de Lorea, atribuye la prolijidad de su pluma a los dones y capacidades recibidos de modo sobrenatural (Poutrin 2015). Bajo este pretendido influjo celestial, sor Hipólita se consagró a la escritura de textos autobiográficos y biográficos, tratados espirituales, comentarios bíblicos y textos de gran vuelo místico..., todo ello escrito en castellano, una lengua que no se correspondía con su habla particular, pero con la que pretendía difundir de manera universal sus obras, en un mercado hispánico hegemónicamente castellano. Como ya es sabido, los capítulos sobrenaturales que experimentaba motivaron el asombro y los recelos de sus directores espirituales, que le pidieron que narrara sus experiencias biográficas y espirituales en cuadernos, para ser examinados con mayor cautela. ${ }^{5}$

\footnotetext{
4 Conocemos los detalles de esta causa gracias a los estudios de Callado (2007: 111-114); y Giordano (2011: 23 y 2012).

5 «Y aviendo reconocido sus confessores (varones muy doctos y de singular espíritu), y repetidas vezes examinado el de dicha Venerable madre y la solidez de sus virtudes y profunda humildad, que la avían grangeado de Dios una soberana inteligencia de los divinos ministros, comprehendidos en la Sagrada Escritura; para que no se malograsse este tesoro escondido, cuya manifestación podía conducir mucho al servicio de Dios y bien de las almas, repetidas vezes le mandaron escriviesse de su mano todo lo que Dios en su oración le inspirasse y enseñasse. Y aunque por su grande humildad se resistió quanto pudo, representando a sus confessores su suma ignorancia para saber explicar de palabra ni de escrito misterios tan altos, fueron tales los impulsos soberanos que tuvo y el conocimiento de su obligación que no pudo negarse a la rendida obediencia de los continuos preceptos de los prelados, que estando en lugar de Dios y en su nombre, le mandaron se resignasse en esto a la obediencia y consejo de los padres espirituales y confessores.
} 
Sin embargo, lo cierto es que la dominica catalana de solariega cuna también dedicó sus días de celda a componer poesía. ${ }^{6}$ Una poesía creada especialmente para ser cantada, que le serviría como a tantas otras monjas poetas de su tiempo (Baranda 2013; Zaragoza 2013 y 2016)- para canalizar sus afectos, así como para alentar la fe y adoctrinar a sus hermanas, asentada en las corrientes de poetización que inspiraron con empuje la poesía religiosa desde la segunda mitad del siglo XVI (Núñez 2005). Sin embargo la producción poética de Hipólita resulta aun escasamente conocida por la crítica, en tanto en cuanto nos ha llegado dispersa a lo largo de su imponente obra imprea, como exhibición de un aparato de santidad (Morujão 1996) ${ }^{7}$. Por eso, en nuestro estudio singularizamos y examinamos la poesía de sor Hipólita de Rocabertí centrándonos en el proceso de transmisión textual de tres de sus poemas, transmitidos por diferentes testimonios, que presentan variantes significativas. Todos estos poemas son de tradición impresa, excepto uno de ellos que se ha conservado también por vía manuscrita. A falta de poder controlar la caligrafía de sor Hipólita de Rocabertí, atendiendo a los problemas de consulta de sus autógrafos, puesto que no podemos confirmar que se trate de un autógrafo, podemos hipotetizar sobre el hecho de que sea un apógrafo. ${ }^{8}$

Todo ello nos permitirá afinar en el aspecto de la edición impresa póstuma promocionada por su sobrino y encomendada a Lorea, y verificar los cuidados puestos en el proceso de impresión, lo que nos llevará a analizar la intervención de elementos ajenos a la autora: datos de gran interés no solo para el estudio de la producción de sor Hipólita y su transmisión textual, sino que se convierten en elementos de análisis a tener en cuenta en el abordaje del proceso de construcción del modelo de perfección cristiana de la escritora. Nuestro propósito final ha sido arrojar nueva luz al estudio de la construcción de la imagen de la autora en que este proceso revirtió y, para ello, partimos de otros estudios recientes consagrados a la religiosa, como los de Isabelle Poutrin (2015), centrado en los paratextos, las censuras y las aprobaciones que constituyen el aparato de autorización de los escritos de la monja, y Rosa María Alabrús (2015a), que ha profundizado sobre el proceso de creación de una determinada imagen de santidad arrojada sobre la dominica.

Executolo assí y premió Dios tanto su rendido obsequio a la obediencia que con el favor divino, en pocos años dexó escritos de su mano passados de cinquenta libros de diferentes assuntos espirituales, repartidos en veinte y quatro tomos, impressos en folio, sin los que quedan aun por imprimir; fundando siempre su dicho en doctrina de la Sagrada Escritura y santos padres, con grande erudición y enseñança para las almas que tratan de virtud» (Rocabertí 1694 [Exposición litera] [Preliminares]).

6 Además, en los últimos años se han exhumado algunas cartas de su correspondencia conventual (Ahumada 2010).

7 Tomamos la expresión de la investigadora portuguesa, que ha estudiado la relación entre poesía y santidad a partir de la inclusión del discurso poético en las biografías de monjas ilustres «como testemunho comprovativo da sua especial intimidade com Deus» (Morujão 1996: 239)

8 Entendemos apógrafo en el sentido de texto controlado por su autora. A pesar de que no hemos podido cotejar la letra del manuscrito con ningún autógrafo de sor Hipólita, porque no tenemos acceso al archivo del antiguo convento de los Ángeles -en el actual monasterio de Sant Doménec en San Cugat (Barcelona)-, todo parece indicar que se copió en el cenobio. 
Verònica Zaragoza Gómez. Censura y edición póstuma de la obra de Hipólita de Rocabertí: a propósito de unos poemas manipulados

\section{Notas sobre la transmisión de la obra poética de sor Hipólita de Rocabertí en el marco del proyecto editorial de su magna obra}

Para empezar, sobre el proceso de edición de la obra completa de sor Hipólita de Rocabertí, sabemos que se llegaron a imprimir póstumamente cerca de veintiséis volúmenes a lo largo de tres proyectos póstumos, de distinta envergadura y promotores. Así, los dos primeros tomos de la dominica vieron la luz entre 1643-1647 por iniciativa de las religiosas del convento de los Ángeles, que pretendían proyectar sobre la comunidad una fama que su religiosa más ilustre había ganado con su pluma y santidad. ${ }^{9}$ A partir del tercer volumen, el proyecto de publicación fue supervisado por el sobrino de Hipólita, quien -como ya se ha avanzado- promovió el proceso de beatificación de su tía apoyándose en sus escritos. Para ello, confió las tareas de edición en la persona de fray Antonio de Lorea, que se había instalado en la capital del Turia para asumir el cometido. ${ }^{10}$ En las prensas valencianas de Vicente Cabrera, Benito Macé (regentada por su viuda), Francisco Mestre, Manuel Gómez González de Lastra y Jaime Bordázar, vieron la luz una gran tirada de volúmenes importantes de sor Hipólita, ${ }^{11}$ en un segundo proceso completado entre los años 1679-1685, coincidiendo con la ya aludida causa de santificación abierta en Roma (Callado 2007: 348-350). Finalmente, pese a la inclusión de algunos títulos hipolitanos en el Índice de librosprobibidos, entre 1687 y 1693 (Callado 2007: 350, n. 833), la publicación de la obra completa de la dominica siguió su andadura entre 1688 y 1694, en la imprenta valenciana de Jaime Bordázar, en una tercera y última fase de edición en la que vieron letra impresa dos volúmenes, uno de ellos con carácter recopilatorio. ${ }^{12}$

\footnotetext{
9 Nos referimos al Tomo primero de los tratados espirituales de sor Hypólita de Jesús de Rocabertí y Soler (1643), que contiene: «primero, de la penitencia, segundo, del temor de Dios, tercero, de la consideración y meditación» y que vino impreso con una carta en los paratextos de la «suspriora dels Àngels», titulada «A la muy noble y fidelíssima ciudad de Barcelona por su Señoría, a los muy Illustres Señores Conselleres y Sabio Consejo de Cento...» (2 f.), y al Tomo segundo de los tratados espirituales de sor Hypólita de Jesús [...] Llamado viage de la celestial Jerusalén, que contiene el Viage de la celestial Iervsalem, y que también incluye una carta firmada por la priora y las religiosas del convento, a Marguerite-Philippe du Cambout, condesa de Harcourt y virreina de Cataluña, que desempeñó «un papel de perfil alto», durante el virreinato de su esposo, el destacado militar y aristócrata francés Henri Harcourt de Lorena, entre 1645 y 1647 (sobre su estancia y funciones en Cataluña, véase el estudio de Pérez Samper (2014).
}

10 Él mismo ofrece detalles sobre su intervención editorial (Lorea 1679: Prólogo): la división en capítulos, y la inclusión de notas al margen.

11 Ahumada (2013: 146-148), que proporciona los títulos, los clasifica y divide en dos colecciones (recurriendo a las letras A y B), según algunas diferencias formales (p.e. la colección B está numerada). Serrano y Sanz (1903-1905: II, 157) describe un impreso que no hemos podido localizar y que tampoco es citado por Ahumada: Perfeto christiano, siguro camino de la perfección, celestiales documentos y evangélicos consejos con admiración enseñados para el mayor adelantamiento de las almas en la virtud. Recogidos de diferentes lugares del primer tomo de la Vida que por mandado de sus confessores escrivió la venerable Madre Hipólita de Iesús y Rocabertí, impressa ya en Valencia (Valencia, Juan Lorenzo Cabrera, 1683).

12 Se trata de Epitome de los veinte y quatro tomos que escrivió la V. M. Hypólita de Jesús y Rocabertí (1688) y Exposición literal, mýstica y moral sobre los lugares más selectos de los SS. Quatro Evangelios (1694).

SCRIPTA, Revista internacional de literatura i cultura medieval i moderna, núm. 8 / desembre 2016 / pp. 194-223 ISSN: 2340-4841 · doi:10.7203/SCRIPTA.8.9295 
Verònica Zaragoza Gómez. Censura y edición póstuma de la obra de Hipólita de Rocabertí: a propósito de unos poemas manipulados

Respeto a la obra poética de Hipólita, si bien ya teníamos noticia de algunos de sus poemas por las menciones de Serrano y Sanz (1903-1905: II, 150-161) y por algunas de sus transcripciones (1915: I, 145-153, algunas de ellas fragmentarias, que a menudo no indicaban la fuente) ${ }^{13}$ la crítica nunca antes había mostrado interés por sistematizar la investigación en este aspecto tan desconocido de la ilustre monja catalana, no por ello menos interesante. Lo cierto es que, hoy por hoy, accedemos a los poemas de la monja dominica gracias al hecho de que fueron incluidos en los volúmenes que alcanzaron la letra impresa: recorrer con la mirada estos libros nos permite adentrarnos en un mundo de expresión lírica excepcional de imágenes y fuentes espirituales de su tiempo. En total, las piezas consignadas son veintiséis, en forma de canciones, romances, cuartillas, serventesios místicos, liras...

Dicho esto, la poesía de sor Hipólita se encuentra intercalada en las últimas páginas de sus libros, a modo de conclusión de sus tratados autobiográficos o exegéticos y espirituales; aunque también irrumpe en el cuerpo central de los impresos, como complemento ejemplarizante del tema que está glosando o explicando su prosa, como es el caso de las poesías que aquí comentamos. Cabe destacar que los versos suelen ir acompañados de interesantes explicaciones, que los enmarcan en un determinado contexto de producción y que nos permiten ahondar en los elementos relacionados con el proceso de enunciación y creación poéticas, en su marco conventual. Y, de hecho, este aspecto confiere una cierta importancia a estos versos, aparentemente dispersos o minoritarios en el conjunto de la obra hipolitana: a diferencia de lo que callan buena parte de las composiciones poéticas de religiosas conservadas en el ámbito hispánico en cancioneros y manuscritos, la poesía impresa contextualizada de sor Hipólita, con dichas acotaciones, refleja un marco concreto de poetitzación (y de creación literaria en general) en el mundo claustral femenino de la época; en otras palabras: refiere el «contexto de producción y consumo inmediatos» de la poesía conventual, estudiados por Baranda (2013) recientemente, y debemos prestarle atención. Y es que estas explicaciones que preceden o siguen a los versos de Hipólita, a menudo aportan una plusvalía interpretativa con la que podemos entender de qué modo la creación poética y los cánticos (aparecen junto con la referencia a himnos y salmos, acompañados de verbos que pertenecen al campo semántico de canto 'cantar', 'decorar') representan para Hipólita una práctica creativa inseparable de su experiencia en la clausura, inspirada en el ambiente de inmersión en la oración y la contemplación, y con una fuerte adhesión a las fuentes bíblicas, tal y como ya dimos a conocer en otra ocasión. ${ }^{14}$

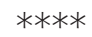

13 Jiménez Faro también transcribió algunos versos en su antología poética femenina (1996: 73-80). Hemos establecimos un corpus poético seguro de sor Hipólita, que enmienda y amplía los datos reportados por Serrano y Sanz en Zaragoza (2013 y 2016).

14 Sobre la línea temática y contexto de estos poemas, léase Zaragoza (2013). 
Pareciome poner aquí una canción en honra y gloria de la seráfica madre nuestra, santa Catalina de Sena, a la qual amava muchíssimo esta religiosa de que hablamos [sor Hipólita]. ${ }^{15} \mathrm{Y}$ acostumbrava quando estava sola en su celda trabajando de manos, a cantar psalmos de David, hymnos de la santa madre Iglesia y algunas canciones de Nuestro Señor Jesuchristo y de sus santos. Vino a sus manos por medio de una otra religiosa muy sierva de Dios esta canción, que un clérigo muy siervo de Dios se la avía dado. ${ }^{16}$ La dicha religiosa [sor Hipólita] hazía sus quadernos y ponía en ellos todo lo que le parecía la avía de mover mucho al dulce amor de su amado Jesús. Y, ansí, puso esta canción, con otras que ella también componía. Pero esta no la compuso ella sino que, en verla, luego la trasladó, y es la siguiente, la qual en cantarla, luego le encendía en el amor de su Esposo Jesús, y nótense con atención las suavíssimas palabras [...] (Rocabertí 1685 [Libro tercero de la vida]: 193). ${ }^{17}$

Por cuanto se puede leer de esta referencia repescada en uno de sus tratados impresos, sor Hipólita encontró en la poesía y en el canto de versos un medio eficaz para demostrar su amor a Jesucristo, a la Virgen y a los santos de los cuales era devota. Todo hace pensar que la dominica confeccionaba sus propios cuadernos con canciones que contribuían a enardecer su devoción y amor divino, enunciadas a menudo en forma de dulce coloquio en cualquier circunstancia de su cotidiana vida conventual. Tal y como refiere ella misma en el sobredicho fragmento, Hipólita no solo recogería los poemas motivados de su propia inspiración, sino que también se dedicó a recopilar la poesía de otros autores espirituales leídos en la época. De hecho, en algunos de sus manuscritos e impresos se localizan algunas composiciones poéticas que no le pertenecen: algunas de ellas son anónimas (y sabemos que son ajenas a su pluma por las introducciones que las preceden); otras, de figuras

15 Cabe explicar que a lo largo de su obra, sor Hipólita recurre al masculino genérico y a la $3^{\text {a }}$ persona para autodesignarse, como el propio confesor le recomendó, por medio de uno de los mecanismos de autolegitimación de las religiosas escritoras de la época como marca de humildad: «Prólogo de la Venerable Madre. Ruego y suplico al que hiziere imprimir este libro que, si le pareciere, que estos cinco primeros capítulos (que son de la misma religiosa) los haga trasladar como en tercera persona, porque estará mejor que todo el libro vaya de una manera, pues en el nombre de N. Señor Jesuchristo le asseguramos ser una misma. Y después de trasladar estos primeros cinco capítulos, como todo el libro, que habla como en tercera persona, se podrán quemar, que ya lo hubiera hecho la misma persona si no fuera por falta de salud. La causa porque lo començó assí fue que, como su confessor le mandasse escribir las mercedes que Dios la hazía en la oración, ella por su humildad empeçó por sus defetos y a contar sus tentaciones; que a las vezes, estas cosas aprovechan más a muchas almas que los mismos consuelos espirituales. Después alteró el modo porque su confessor, que era grande teólogo y muchos años director de ella, la aconsejó que todo lo escriviesse en tercera persona; y como ella, desde que conoció a Nuestro Señor Jesuchristo, siempre deseó y aun procuró no ser conocida, le bino esto muy bien, y assí lo hizo en todos los libros que después deseó escrivir» (Rocabertí [Libro primero de su vida]: 1679: 2). Basta revisar una de las reflexiones de sor Hipólita sobre la autoría de uno de sus poemas, para descubrir esta retórica de la humildad propia de la literatura conventual femenina de la época: «Pues la costumbre es dezirse en los libros el nombre del autor, ya lo tengo dicho muchas vezes que mi propio nombre es el vil gusano» (Rocabertí 1685 [Libro segundo Mýstica]: 511).

16 Eneste sentido, convieneno olvidarlas palabras deBaranda cuando considera que: «La poesía forma parte de este trasiego informativo e incluso formativo, oral y escrito, que intercambian las monjas con quienes las rodean y con otros conventos y en este sentido cuando toca temas religiosos resulta particularmente apta para ser incorporada a su modo de vida» (2013).

17 Posteriormente, setranscribe un poema, de autoría desconocida, con incipit«Elcorderoanda bolando...»(Rocabertí1685 [Librotercerodelavida]:193-194); situadoinmediatamenteantesdelaprotestación, sirveparacerrarlaprimerapartedelimpreso.

SCRIPTA, Revista internacional de literatura i cultura medieval i moderna, núm. 8 / desembre 2016 / pp. 194-223 ISSN: 2340-4841 · doi:10.7203/SCRIPTA.8.9295 
místicas encumbradas, que se entremezclan con los poemas de sor Hipólita, tal vez para marcar una determinada línea de mística y espiritualidad que la habría influido. ${ }^{18}$ Sin embargo, ninguno de esos cuadernos personales con poesía de la monja se ha podido encontrar en el conjunto de manuscritos conservados en el fondo antiguo del convento de los Ángeles -en el actual monasterio de Sant Doménec en Sant Cugat (Barcelona)-, tal y como se desprende del estudio de Ahumada realizado sobre el mismo (2013: 142-146). Gracias a dicho estudio, sabemos que el actual archivo conventual de Sant Doménec custodia once ejemplares manuscritos de la obra de sor Hipólita, pero tan solo una de sus composiciones poéticas se ha conservado manuscrita (Apéndice [1]), mientras que el resto de poesía es de tradición impresa. ${ }^{19}$ De esta tradición impresa, resulta interesante remarcar, además, la existencia de dos poemas con variantes no autoriales (Apéndice [II] y [III]) que proceden de lo que parecen ser dos emisiones diferentes de una misma edición. ${ }^{20}$ Así, los dos estadios de las composiciones evidencian un proceso de revisión y correcciones por parte de los impresores.

En efecto, el cotejo de los diferentes testimonios conservados de los tres poemas nos permite rastrear e ilustrar interesantes prácticas de acomodación de los textos femeninos por parte de las autoridades competentes (¿confesores, editores o tipógrafos?), quienes revisan y 'corrigen' estos textos de monjas (sin ningún tipo de pudor y según sus propios intereses) en el paso del manuscrito a la imprenta póstumamente. De hecho conocemos la revisión a la que fueron sometidos los libros de sor Hipólita en el marco de la segunda fase de edición orquestada por el arzobispo de Valencia, gracias a los 'Prólogos del editor' (presumiblemente obra de Antonio de Lorea) que explican algunos de los detalles sobre los trabajos de corrección y revisión realizados en los primeros volúmenes que habían pasado por la imprenta barcelonesa, en la fase inicial de 1643 y 1647, como ya se ha explicado:

18 Según Ahumada (2013: 142) el primer volumen manuscrito de la obra Sobre las mercedes recibidas de Dios. Autobiografía (4 vol., escritos entre 1604-1614) contiene canciones y poemas de religiosos, en páginas sin numeración. Mientras que en el primer volumen de la autobiografía impresa encontramos solo cánticos y himnos latinos a los que la monja era devota, en el segundo encontramos piezas de Pseudo-Dionisio, del místico franciscano Bernardino de Laredo (1482-1549), del carmelita descalzo Juan de la Cruz (1542-1591), del humanista y teólogo franciscano Diego Pérez de Valdivia (1510-1589) -quien ejerció de confesor de la propia Hipólita y dedicó su Tratado de la singular y puríssima concepción de la madre de Dios, y una exposición sobre los cantares, para predicadores y devotos, compuesto con muy alto y devoto estilo por el doctor Diego Pérez de Valldivia, dirigido a la muy illustre dona Hierónyma de Rocabertín, priora del monasterio de N. S. de los Ángeles de Barcelona (Barcelona, en la imprenta de Gabriel Graells y Giraldo Dotil, 1600), a la tía de Hipólita-, del franciscano Juan de Calatrava, junto con otras de un autor anónimo franciscano. Es necesario cotejar las composiciones localizadas en los impresos con las que recuperan los manuscritos, para dilucidar exactamente qué poesía se ha transmitido por vía autógrafa, así como establecer las variantes. Sin embrago, se trata de un trabajo que actualmente no podemos realizar por falta de acceso a estos materiales manuscritos.

19 Para la lista completa de manuscritos y sus respectivas signaturas, léase Ahumada (2013: 142-148), de los cuales describe minuciosamente el primero de ellos. A falta de una prospección del archivo, nos basamos en este trabajo. De igual modo, agradecemos a esta investigadora las noticias que nos ha proporcionado acerca de los materiales poéticos manuscritos de sor Hipólita conservados en dicho fondo, como el testimonio manuscrito de «Pues estoy en el destierro...».

20 Para el concepto de ‘emisión’ véase J. Moll (1979: 57-76). Queda pendiente un análisis de los ejemplares conservados de sor Hipólito para concretar el alcance de estas nuevas emisiones de ediciones. 


\begin{abstract}
Lo que en esta segunda impresión, se ha trabajado en corregir las muchas erratas que el poco cuidado ocasionó en la primera, en comprovar y reducir las autoridades assí bíblicas como de santos padres, a la pureza que gozan en sus fuentes, y en añadir infinitas citaciones marginales que la impressión de Barcelona, tanto en el Sermón como en los tres libros que comprehende este tomo, casi totalmente omitió ${ }^{21}$ (pues si alguna trae o está errada u dimidiada, no es fácil declarallo, podrase ver, comprovando ambas impressiones. Y, para ayor limpieza, se han sacado en su tabla algunos leves yerros de impressión, que aunque el cuidado ha sido grande, ha sido humano, para que según ella, pueda el letor retocar esta obra y gozar con quieta atención de dotrina tan dulce y saludable. Vale (Rocabertí 1685 [Tomo tercero. De la Penitencia] [Prólogo, 4]).
\end{abstract}

En definitiva, son dichas autoridades competentes las que, a lo largo de dicho proceso editorial, manipulan y rehacen las obras femeninas 'para mejorarlas', sin considerar que el origen de las obras de religiosas es indisociable a su contexto conventual de producción y consumo inmediatos (Baranda 2013: 165-166), lo que explicaría la presencia de ciertos errores que se advierten, por ejemplo en la poesía de la monja dominica, y que son subsanados por sus editores. Teniendo en cuenta que la poesía de monjas impresa en sus hagiografías es concebida por los editores, los biógrafos, como «un elemento da perpeção selectiva que reconhece nas biografadas uma reputação de santidade» (Morujão 1996: 239), del mismo modo y manera, en este proceso de edición de la obra completa de sor Hipólita acometido por Antonio de Lorea, los versos publicados en el libro que comentamos son pulidos y depurados en el segundo estadio impreso, exactamente bajo la consideración de la poesía como manifestación virtuosa, de prestigio, reflejo de la perfección espiritual de su autora. Y por ello, deben rozar la perfección.

A lo sumo, los testimonios que reportamos aquí son un hallazgo muy valioso, ya que nos posibilita documentar prácticas de «elaboración intelectual de firma autorizada (masculina)» (Baranda \& Marín 2014: 15) en la escritura de las religiosas de la época, que van más allá de los casos prototípicos: las memorias conventuales, las Vidas o biografías de monjas, muchas de las cuales se transmitieron como textos oficiales tras haber sido censurados por los cronistas (masculinos) de la orden religiosa o del convento, que los publican a su nombre, parafraseándolos o citándolos según su conveniencia (Peña 1999). Veamos ahora de qué manera se concretan estas prácticas en la poesía de Hipólita, que nos ha llegado mediatizada por una censura aplicada por los editores y/o impresores, con el fin de corregirla, mejorarla o adecuarla al modelo ortodoxo de religiosidad femenina de la época.

21 Se refiere al Tomo primero de los tratados espirituales de sor Hypólita de Jesús de Rocabertí y Soler (1643), en el que se imprimió, además, el Sermón de su vida y honras de la religiosa predicado por el jesuita Jaime Puig. 
Verònica Zaragoza Gómez. Censura y edición póstuma de la obra de Hipólita de Rocabertí: a propósito de unos poemas manipulados

2. Del manuscrito a la imprenta: acerca de los procesos de revisión y la reescritura de la poesía de sor Hipólita

Con el fin de repasar los procesos de revisión y reescritura de la obra impresa de sor Hipólita, es interesante examinar brevemente tres de los poemas de sor Hipólita que fueron publicados en la edición Tratado dividido en quatro libros. El primero contiene: la exposición literal y mística de los psalmos penitenciales; el segundo, la preparación para la muerte; el tercero, coloquios del alma christiana con Dios; el quarto, fundamento sólido de la oración por ser todo fundado en el santo Evangelio (Valencia, Jaime de Bordázar, 1683):

\begin{tabular}{|c|c|c|c|}
\hline & & Testimonios & Edición \\
\hline $\begin{array}{l}\text { "Pues estoy en el } \\
\text { destierro...» }\end{array}$ & $\begin{array}{l}\mathrm{A} \\
v\end{array}$ & $\begin{array}{l}\text { Archivo del Monasterio de los Angeles de San } \\
\text { Cugat, s.p. } \\
\text { Tratado dividido... Valencia, Jaime Bordázar, 1683, } \\
\text { pp. 520-525. } \\
1 \text { AMA, Ms. P2/15. } \\
2 \text { En cuanto a la edición de este poema, coincide } \\
\text { en todos los ejemplares consultados: BUB, } \\
\text { Reserva, } 07 \text { C-210/3/5, 07 C-210/3/6 y 07 } \\
\text { C-211/3/14 y BNCR, 8. 39.L.15, razón por la que } \\
\text { no especificamos el ejemplar consultado. }\end{array}$ & $\begin{array}{l}\text { Poema I de nuestro } \\
\text { apéndice }\end{array}$ \\
\hline
\end{tabular}

SCRIPTA, Revista internacional de literatura i cultura medieval i moderna, núm. 8 / desembre 2016 / pp. 194-223 


\begin{tabular}{|c|c|c|c|}
\hline \multicolumn{3}{|c|}{ Testimonios } & \\
\hline $\begin{array}{l}\text { «Aunque estoy } \\
\text { cautiva en } \\
\text { Babilonia...» }\end{array}$ & $v^{\prime}$ & $\begin{array}{l}\text { Biblioteca Nazionale Centrale di Roma, Tratado } \\
\text { dividido... Valencia, Jaime Bordázar, 1683, pp. 442- } \\
443 .^{3} \\
\text { Biblioteca Universidad de Barcelona, Tratado } \\
\text { dividido... Valencia, Jaime Bordázar, 1683, pp. 442- } \\
443 \text { [estadio 2]. }{ }^{4} \\
\text { 3 BNCR, 8.39.L.15. Consultadoa través de unacopia } \\
\text { digital. Procedente de la Biblioteca del Convento } \\
\text { di San Bonaventura al Palatino, de Roma, habría } \\
\text { pertenecido al cardenal Pier Matteo Petrucci } \\
\text { (1636-1701), famoso quietista italiano que vio } \\
\text { prohibidos numerosos de sus tratados espirituales. } \\
4 \text { En la BUB, Reserva, hemos podido consultar } \\
\text { tres ejemplares de la misma edición: } 07 \text { C-210/3/5, } \\
\text { 07 C-210/3/6 y 07 C-211/3/14, aparentemente } \\
\text { iguales. Sin embargo, presentan al menos algunas } \\
\text { divergencias en los paratextos, por cuanto unos } \\
\text { traen el conocido grabado de la religiosa, pluma en } \\
\text { mano y rodeada de sus libros (véase en Apéndice) } \\
\text { y una protesta que había mandado poner el } \\
\text { arzobispo de Valencia, sujetándose en los decretos } \\
\text { de la santidad de Urbano VIII (1625, } 1631 \text { y 1634). } \\
\text { En cuanto a este y al siguiente poema, los tres } \\
\text { ejemplares de BUB presentan la misma emisión, por } \\
\text { lo que no especificamos la referencia topográfica. }\end{array}$ & $\begin{array}{l}\text { Poema II de nuestro } \\
\text { apéndice }\end{array}$ \\
\hline
\end{tabular}

\begin{tabular}{|c|c|c|c|}
\hline & & $\overline{\mathrm{Te}}$ & \\
\hline $\begin{array}{l}\text { «Haciendo } \\
\text { el sacrificio } \\
\text { vespertino...» }\end{array}$ & $\begin{array}{l}v \\
v^{\prime}\end{array}$ & $\begin{array}{l}\text { Biblioteca Nazionale Centrale di Roma, Tratado } \\
\text { dividido... Valencia, Jaime Bordázar, 1683, pp. } 443- \\
445 .^{5} \\
\text { Biblioteca Universidad de Barcelona, Tratado } \\
\text { dividido... Valencia, Jaime Bordázar, 1683, pp. } 443- \\
445 \text { [estadio 2]. } \\
5 \text { Véase nota } 3 \text { de esta tabla. } \\
6 \text { Véase nota } 4 \text { de esta tabla. }\end{array}$ & $\begin{array}{l}\text { Poema III de } \\
\text { nuestro apéndice }\end{array}$ \\
\hline
\end{tabular}


Verònica Zaragoza Gómez. Censura y edición póstuma de la obra de Hipólita de Rocabertí: a propósito de unos poemas manipulados

El primero de los poemas que hemos examinado es el romance «Pues estoy en el destierro...» ${ }^{22}$ del que -como antes hemos comentado- también se ha conservado un testimonio manuscrito, que si no es un autógrafo, consideramos que podría tratarse de una copia controlada por la autora, transmitida en una hoja suelta del archivo conventual. ${ }^{23}$ En esta composición la voz poética se siente apartada de su Esposo y quiere comunicarse con él a través de un billete (carta) para que la libre del desasosiego y los desvelos del alma que le ocasiona su ausencia. ${ }^{24}$ A continuación del romance se puede leer un comentario de la autora que, con el obligado tono de humildad, especifica la intención en la creación de estos 'cánticos': incitar la devoción divina, la misma motivación que había movido a Francisco de Asís, con sus cánticos simples:

\begin{abstract}
Acuérdome que el seráfico padre san Francisco con mucha llaneza compuso cánticos para mover a devoción, no solo a sus hijos los religiosos menores, aunque yo los tengo por mayores dentro de mi coraçón, pero también le movió a zelo, como se lee en su primera crónica para incitar a devoción a todos los christianos presentes y aun a los venideros. Assí, yo vilíssima y miserable, he compuesto estos cánticos, aunque no, no cierto con la santidad deste glorioso padre, pero con la misma llaneza de intención con que él lo hizo, que es por mover a devoción a mis hermanos y padres y predicadores, assí religiosos como religiosas; y después, a todos los christianos. Y ruego perdonen las faltas que en ellos y en todos mis escritos hallaren, pues mi rudez no alcança más (Rocabertí 1685 [Tratado dividido en quatro libros]: 525).
\end{abstract}

Ciertamente, tal y como ya hemos ido avanzando, el análisis de las variantes del texto manuscrito del poema permite verificar ciertas alteraciones del texto manuscrito aplicadas en su versión impresa póstuma, lo que nos lleva a conjeturar que se trataría de una copia intervenida por los editores, cuando su autora ya no podía revisar sus autógrafos. Como se puede ver en el aparato de variantes

22 Este poema comparte el mismo tono y contenido que el que empieza con los versos «Pues me veo en este valle / apartada de mi Esposo / este billete le halle / en que le pido reposo... » (Rocabertí 1685 [Libro tercero de la vida]: 70 71), que fue transcrito fragmentariamente: «Por evitar prolixidad dexamos más de treynta versos, pero quien ama a Jesús basta lo dicho: para quien no ama, no le queremos molestar con tanta prolixidad de los versos, que dexamos. Soli Deo Honor \& gloria» (p. 71). Fue copiado por Serrano y Sanz (1903-1905: II, 158-159), junto con otro, sin solución de continuidad.

23 Lleva por rúbrica: «Cantico que compuso la v.m sor Hipolita de jesus ÿ Rocaberti Religiosa del P.S. Domingo».

24 Se encuentra impresa en el capítulo XVII «Prosigue la misma materia y que en el Cielo se cantan hymnos de alabanças a Dios: el autor, en honra de su amado Jesuchristo, compone cánticos de alabança y en honra de sus profetas le dan testimonio de su amado Jesús. Y todo lo que sigue, se funda sobre la petición: Adveniat Regnum tuum», del tratado Fundamento sólido de la oración.., junto con otras piezas poéticas y va precedida de la nota: «Pues por ser la santa y divina Escritura reyno de los cielos y por obedeçer a ella, vamos al reyno de los cielos; [...] Ahora también por sola honra y gloria del santo nombre de mi amado, quiero traer otro cántico que solo trata del vivo deseo que yo, vilíssimo gusano, tengo de salir de la cárcel deste cuerpo mortal; por no más ofender en nada al dulçe Jesús y por cumplir perfectamente su divina ley encendida, porque en esta miserable vida no le puedo amar tanto como yo quisiera, pero allá en su reyno amaré al Verbo Divino humanado con su Padre y con el Espíritu Santo un solo Dios verdadero Trino y Uno, con todo mi coraçón y alma, sin descansar, ni cessar de amar a Dios perpetuamente» (Rocabertí 1685 [Tratado dividido en quatro libros]: 520). 
del poema (Apéndice [1]), las variantes no autoriales se fundamentan en el cambio de las marcas de género de la voz poética enunciadora: así, la voz femenina de la versión manuscrita, es reemplazada por la voz masculina en el impreso, solo cuando la rima lo permite. Inevitablemente, este cambio, en ocasiones forzado, ocasiona algunas incoherencias en el texto, ya que solo por imperativo de la rima se han mantenido las marcas genéricas en femenino (aparentemente propias del original) y han sido sustituidas por un masculino genérico cuando ha sido posible, como si con ello se pretendiese hacerlo llegar al amplio público lector en la forma masculina (más universal). Del mismo modo y manera, se editó la prosa de sor Hipòlita, en $3^{a}$ persona y en masculino, como ya se ha visto. De todo ello, son muestra la presencia en el testimonio impreso del adjetivo apartado (v. 1 y 37), frente a las formas mendiga (v. 14), herida (v. 66), rendida (v. 70) y perdida (v. 74) en posición final de rima, así como la aparición de la voz enunciadora masculina en los únicos testimonios conservados, impresos, de las otras dos composiciones que recoge el mismo volumen, que podría responder a la misma operación de cambio de género en el paso del manuscrito a la imprenta. Así, en el texto impreso que nos ha llegado del segundo poema «Aunque estoy cautiva en Babilonia...» [II] leemos adjetivos como cautivo (v. 1) o las expresiones me ofrezco a mí mismo (v. 20), lecciones que hemos restituido por la correspondiente forma femenina, contra la tradición, porque consideramos que debe ser de una modificación enmarcada en el proceso editorial. ${ }^{25}$

Desgraciadamente, no conservamos ningún otro testimonio manuscrito que nos permita confirmar las prácticas intervencionistas detectadas en esta pieza para el resto de la poesía de sor Hipólita, aunque nos parece suficiente para considerarlo una constante en la edición de su obra poética, e incluso de su prosa. De hecho, todo ello nos interpela a preguntarnos sobre el grado de conocimiento de la autora acerca de esta intervención editorial, en la modificación y revisión de la propia obra (quizás en un estadio intermedio conocida por ella misma, que ahora desconocemos).

Por lo que respecta a los otros dos poemas que hemos editado, impresos en el Tratado dividido en quatro libros (pp. 442-445) y que son objeto de estudio de este trabajo, nos han permitido advertir un dato insospechado y revelador: la existencia de variantes no autoriales entre los textos de los dos poemas, en varios de los ejemplares consultados de la edición, tanto en la Biblioteca de la Universidad de Barcelona como en la Biblioteca Nazionale Centrale di Roma, como se puede leer en el cuadro de testimonios aportado más arriba. Se trata del romance heroico «Aunque cautiva estoy en Babilonia...» (Apéndice [II]) y del poema en octavas «Haciendo el sacrificio vespertino... $»^{26}$ (Apéndice [III]) impresos correlativamente en el mismo libro, que remiten ambos al destierro

25 Consideramos que esta restitución, además, podría resolver ciertos problemas relativos a la rima (los versos «Aunque estoy cautivo en Babilonia, / del pueblo de Judá tan apartada, / de ti, Jerusalem, joh!, ciudad santa, / de ti mi corazón nunca se aparta», v. 1-4, de la primera emisión, se transforman en «Aunque cautivo estoy en Babilonia, / del pueblo de Judá tan apartado, / de ti, Jerusalén, joh!, ciudad santa, / no se apartan mis ojos y mi llanto» en la emisión posterior, enmendada por los editores). En lo que concierne al poema [III, A] no hemos hallado marcas de género en la voz poética, más allá de la explicitación: «soy hombre...» (v. 35), que podría responder a una manipulación de los editores.

26 Tras este poema, se puede leer la nota: «Pido perdón si el verso está mal hecho porque en mi vida me precié de

SCRIPTA, Revista internacional de literatura i cultura medieval i moderna, núm. 8 / desembre 2016 / pp. 194-223 ISSN: 2340-4841 · doi:10.7203/SCRIPTA.8.9295 
babilónico del pueblo de Israel. A lo sumo, las dos versiones aludidas proceden de dos emisiones diferentes de la susodicha edición (y que se corresponden a los testimonios poéticos de $v$ y v), que comparten portada y datos de imprenta (Valencia, Jaime de Bordázar, 1683). Es necesario explicar que, en dos de los tres volúmenes consultados en la BUB, el pliego con las dos poesías fue recortado $\mathrm{O}$ arrancado (quedando en un caso suelto), ${ }^{27}$ y sustituido por otro, con un nuevo estadio de los poemas. El hecho de que se trate de un pliego sustituido explica que tan sólo encontremos variantes en las piezas que comentamos, pero no en otros de los poemas impresos la edición, transmitidos idénticamente en todos los ejemplares (inclusive el poema [1] del que ya hemos hablado).

Efectivamente, la existencia de dos versiones de los textos [II] y [III] apuntan hacia una intervención en el proceso editorial y son reflejo de una compleja e intrincada transmisión textual de la que solo podemos proporcionar unas breves notas ahora, pero que a todas luces debe vincularse con el proceso de promoción del modelo de santidad de la autora, Hipólita de Rocabertí. Puesto que los testimonios de la BUB son nuevas versiones de los dos poemas (representados con la sigla $v^{\prime}$ ), los hemos editado confrontados con los testimonios de la BNCR (correspondientes a $v$ ), lo que nos permite verificar las modificaciones operadas en estos versos de sor Hipólita por parte de los agentes editoriales. En resumen, la naturaleza de las variantes introducidas en v' nos lleva a pensar en los esfuerzos de los editores por mejorar, al menos estos dos poemas en una segunda emisión: el pliego que los contenía fue sustituido en algunos impresos de la BUB, tal y como se puede advertir de las páginas arrancadas o recortadas y de la existencia del pliego suelto con los poemas ya modificados, en algún ejemplar, tal y como ya se ha explicado.

Así pues, con el cambio que observamos en los poemas [II] y [II], en la nueva emisión de los mismos $(v)$ se advierte una mejora del texto, especialmente desde el punto de vista de la versificación. Con ello, si tenemos en cuenta las modificaciones efectuadas, debemos destacar los editores intentaron enmendar algunos problemas de rima irregular y métrica detectados en $v$, aunque la corrección de los versos hipométricos e hipermétricos implicasen cambios notables en el contenido de los mismos. Asimismo, las nuevas variantes sobre el texto demuestran los intentos de subsanar ciertas erratas de imprenta, presentes en $v$ y de eliminar de los textos las grafías o formas arcaicas («Ierusalem» per «Gerusalen»y «hagora» per «aora», que transmitía la primera versión del poema «Haciendo el sacrificio vespertino...»). De hecho, siguiendo con esta intención de mejora de los textos, los editores modificaron incluso, la definición de los dos poemas en la descripción que los introducen: ${ }^{28}$ pasan a ser

Poeta. Y assí, no se atienda tanto al arte quanto al afecto» (Rocabertí 1683 [Tratado dividido en quatro libros]: 445).

27 BUB, 07 C-210/3/5 y 07 C-210/3/6: en el segundo de los ejemplares, el pliego de folios con los poemas coincide con un error en la paginación: de la p. 438 pasa a las pp. 441-444, y de nuevo a las pp. 439-440; el pliego siguiente ha sido arrancado en las páginas 441-444, con los poemas, situadas anteriormente. ya habían aparecido antes; a continuación, aparece directamente la p. 445. En el impreso 07 C-211/3/14 ya no se advierte ningún error en la paginación y el pliego con la poesía se ha conservado intacto.

28 Como el anterior, fueron impresos en el libro Fundamento sólido de la oración, uno de los cuatro que recoge el Tratado dividido en quatro libros..., 1683, concretamente en el capítulo VI que «Habla en verso de aquellas palabras, que dize el 
presentados con la forma genérica «poesía» (o «Hymnos sacros» ${ }^{29}$ según la rúbrica), más adecuada por la forma métrica, considerando que antes aparecían como «canción o soneto» («canción» en la rúbrica), en el caso de la primera pieza, ${ }^{30}$ y como «canción», la segunda, ${ }^{31}$ y no se correspondían a esta denominación.

En conclusión, las intervenciones que presentan los testimonios $v^{\prime}$ de los dos poemas respecto a los de $v$ conciernen tanto al orden de las palabras como a la introducción de nuevos matices de sentido en los versos, de manera que cabría considerar como buenas las variantes de los textos de $v$, que se corresponde a la emisión de la Biblioteca Nazionale Centrale di Roma. Lo que se deduce de todo este análisis es que la modificación del discurso poético de sor Hipólita en su versión impresa y la ingerencia de los agentes editoriales (posiblemente el padre Lorea, bajo órdenes del arzobispo Rocabertí) en este proyecto de edición clarifica el grado de autoridad débil que presentan estos textos de monjas: no solo porque fueron desposeídas de su poder de control sobre la propia obra, al ser editada solo póstumamente en el marco de una campaña de santidad, sino porque se les desvirtuó su 'yo autorial', con mecanismos que fueron más allá de la manipulación de la voz poética.

ángel al Profeta Daniel, cap. 9. Vir desideriorum. Y de aquellas otras: Et adducatur iustitia sempiterna, \& impleatur visio, \& Profetia, \& ungatur sanctus Sanctorum. Y de las otras palabras: Et post hebdomades sexaginta duas occidetur Christus».

29 Díaz Rengifo define los Hymnos como: «[...] los cantos en metro que se cantan en alabanza y gloria de Dios y sus santos. Dice San Agustín: Hymni cantus sunt continentes laudes Dei; se sit laus \& non sit Dei, non est Hymnus. Sin que por esto dexen de fer hymnos los que son en alabanza de los santos, porque las alabanzas de los santos son especialmente de el mismo Dios como consta de el Psalmo 150: Laudate Dominum in Sanctis ejus; y quizás por esta causa acaba la Iglesia los hymnos alabando a Dios en la última estropha. Constan ordinariamente de poemas lýricos y de muchos géneros de poesías assonantes [...]» ([1759]: 149-150).

$30 \mathrm{El}$ poema es introducido por la nota explicativa que sigue: «Por ser el autor muy aficionado a este santo profeta y también por consuelo de quien dello quisiere aprovechar, compuse una canción o soneto deste santo profeta; y nótense las palabras, porque no pretendemos salirnos un punto de la santa y divina Escritura. Una misma verdad es, que esté en verso o no, poco va en ello; sino lo que importa es que nos aprovechemos de la viva palabra de Dios, poniéndola por obra» (Rocabertí 1683 [Tratado dividido en quatro libros]: 441 [II,A]). En la segunda emisión, la descripción cambia ligeramente como: «Por ser el autor muy aficionado a este santo profeta y también por consuelo de quien dello quisiere aprovechar, compuse una poesía deste santo profeta; y nótense las palabras, porque no pretendemos salirnos un punto de la santa y divina Escritura. Una misma verdad es, que esté en verso o no, poco va en ello; sino lo que importa es que nos aprovechemos de la viva palabra de Dios, poniéndola por obra» (Rocabertí 1683 [Tratado dividido en quatro libros]: 441 [I, B]).

31 El poema es presentado con el texto «Esta última canción trata de las mercedes y revelaciones que el Espíritu Divino hazía al santo profeta Daniel, y es al mismo tono que el passado. Y trata del encendido amor con que deseava la venida de nuestro Señor Iesu Christo» (Rocabertí 1683 [Tratado dividido en quatro libros]: 443 [A]), que cambia levemente en la segunda emisión, tan sólo en la denominación de la pieza: «Esta última poesía trata de las mercedes y revelaciones que el Espíritu Santo hazía al santo profeta Daniel, y es al mismo tono que el passado. Y trata del encendido amor con que deseava la venida de nuestro Señor Iesu Christo» (Rocabertí 1683 [Tratado dividido en quatro libros]: 443 [B]). 
Verònica Zaragoza Gómez. Censura y edición póstuma de la obra de Hipólita de Rocabertí: a propósito de unos poemas manipulados

\section{Conclusiones}

En suma, desde una perspectiva de análisis inédita, en nuestro artículo hemos reflexionado acerca del proceso de la transmisión, fijación y edición de algunas de las poesías de Hipólita de Rocabertí, integrándolas en el complejo proceso editorial orquestado por su sobrino en la segunda mitad del siglo XVII. Así pues, como complemento de los datos ya conocidos sobre dicho proceso editorial y la circulación de las obras de Hipólita de Rocabertí, al cual hemos atendido en la primera parte del artículo, hemos mostrado como el procedimiento de censura y manipulación de algunas de las poesías de la religiosa pasa a ser un requisito previo a su paso por la imprenta. Lo demuestra el análisis de variantes con divergencias significativas en varios testimonios de tres de sus poemas que hemos revisado en la segunda parte del trabajo. Con estos datos y con la edición misma de los textos, que se presentan con los testimonios confrontados en el apéndice, se refuerza la hipótesis de un previo acomodamiento e intervención por parte de los editores para con los poemas autógrafos antes de la publicación póstuma, y las correcciones a las que se someten estos materiales a lo largo del proceso de impresión, que debe ser estudiado con más profundidad. Sin embargo, las hipótesis y los problemas que presentamos aquí sobre la diversidad en la transmisión de los testimonios de estos tres poemas de Hipólita, que apuntan hacia una intervención posterior, deben ser perfilados y resueltos con análisis más profundas sobre los textos, con la aparición de nuevos testimonios que nos permitan ampliar nuestras interpretaciones y restablecer el conocimiento de la obra de unas de las autoras más fascinantes y sugerentes del período. 
Verònica Zaragoza Gómez. Censura y edición póstuma de la obra de Hipólita de Rocabertí: a propósito de unos poemas manipulados

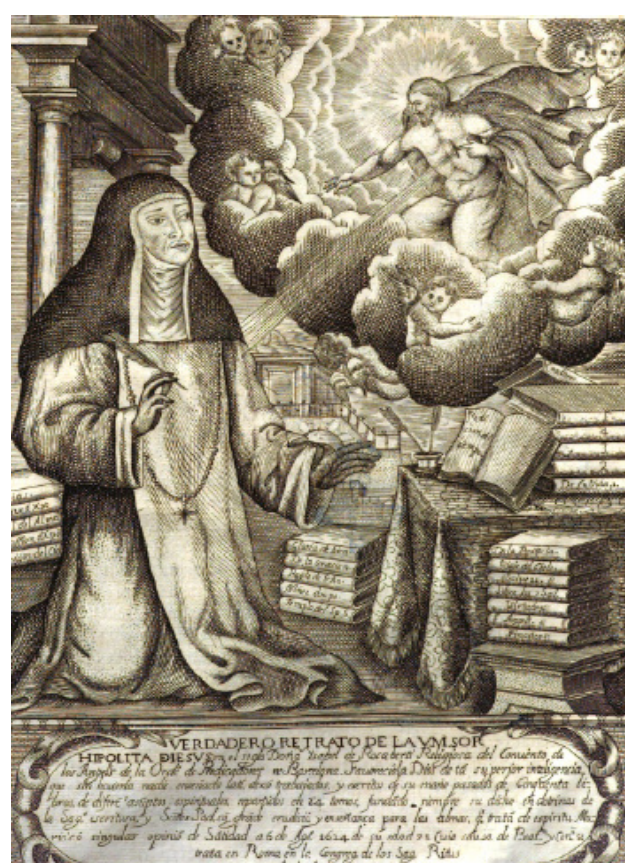

Ilustración. Retrato de la V.M. sor Hipólita de Jesús, incluido en Tratado dividido en quatro libros... [Verdadero retrato de la V.M. sor Hipólita de Jesús, en el siglo doña Isabel de Rocabertí, religiosa del convento de los Ángeles de la orden de Predicadores, en Barcelona. Favoreciola Dios de tan superior inteligencia que, sin haberla nadie enseñado latín, dejó trabajados y escritos de su mano pasados de cincuenta libros, de diferentes asuntos espirituales, repartidos en 24 tomos, fundando siempre su dicho en doctrinas de la Sagrada Escritura y Santos Padres con grande erudición y enseñanza para las almas, que tratan de espíritu. Murió con singular opinión de santidad a 6 de Agosto 1624 de su edad 73. Cuya causa de beatificación y canonización se trata en Roma en la Congregación de los Sagrados Ritus desde el Año 1676] (1683) 
Verònica Zaragoza Gómez. Censura y edición póstuma de la obra de Hipólita de Rocabertí: a propósito de unos poemas manipulados

\title{
APÈNDICE I.
}

\section{EDICIÓN DE LOS TEXTOS ${ }^{32}$}

\author{
$[1]$
}

«Pues estoy en el destierro»

Pues estoy en el destierro

apartada de mi dicha, quiero escribir a mi Amado y a su piedad compasiva.

Aunque es Señor de señores y Rey de reyes se firma, al principio del billete Padre amoroso se cifra.

¿Quién sois Vos, suma Grandeza, y quién, mi bajeza indigna? Vos solo sois el que sois y la nada es propria mía;

Vos, la gloria de los cielos, yo, la más pobre y mendiga; mis miserias os refiero porque a piedad os incitan.

La mayor de todas ellas, no amaros como querría:

Ex tot corde es ex mente 33 con voluntad siempre fina.

Suave es vuestro precepto que a amaros al hombre obliga, otra cosa no deseo sino amaros, Vida mía; que sois la misma bondad digna de ser conocida, $y$ en conoceros y amaros consiste mi mayor dicha.

Abrasadme con el fuego de vuestra llama infinita y que ardiendo en vuestro pecho en él descanse, en él viva.

$\mathrm{Y}$, pues aquesto es verdad, oh, caridad sin medida, sacad mi alma del cuerpo porque os vea noche y día.

32 Edición, en parte, procedente de nuestra tesis doctoral, inédita (Zaragoza 2016).

3319 Cfr. Mc. 12:30.

SCRIPTA, Revista internacional de literatura i cultura medieval i moderna, núm. 8 / desembre 2016 / pp. 194-223 
Verònica Zaragoza Gómez. Censura y edición póstuma de la obra de Hipólita de Rocabertí: a propósito de unos poemas manipulados

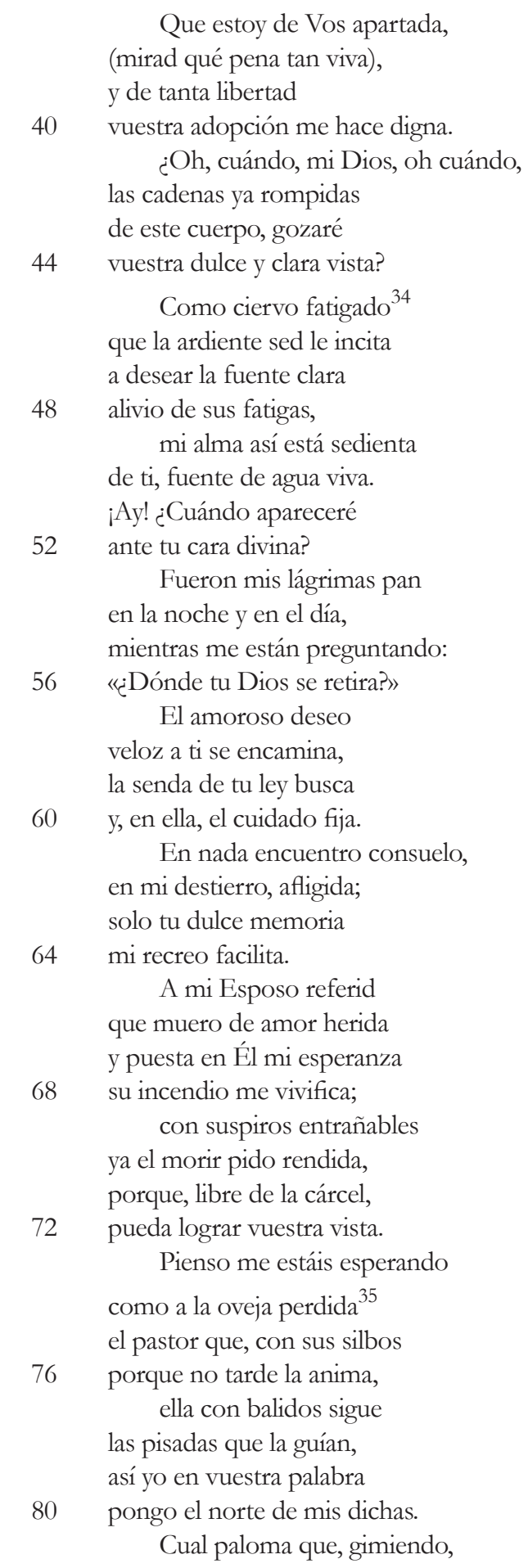

3445-48 Cfr. Salmos 42:1.

3573-80 Clara alusión a la parábola bíblica de la oveja perdida (cfr. Lc. 15:3-7 y Mt. 18:10-14).

SCRIPTA, Revista internacional de literatura i cultura medieval i moderna, núm. 8 / desembre 2016 / pp. 194-223 
Verònica Zaragoza Gómez. Censura y edición póstuma de la obra de Hipólita de Rocabertí: a propósito de unos poemas manipulados

bosques y selvas registra,

sin que en el diluvio humano

84

encuentre donde el pie imprima, así mi alma muriendo

al celeste puerto aspira

y hasta que tal suerte logre,

88 el destierro la fatiga.

Mi vida es por ti morir

y sufrir penas crecidas,

tus encendidos amores

92 a tal finezas me obligan;

estoy con mil pensamientos

que mi dolor multiplican:

que no debo estar dispuesta

96 que tanto favor consiga.

Si la caridad ardiente

con su lámpara encendida

bien encendida estuviese,

100 de su reino gozaría.

Va creciendo mi destierro,

ya lo siento cada día,

cada hora estoy gimiendo

104 ¿cuándo será la partida?.

$\mathrm{Ni}$ amigos ya ni consuelos

tengo en esta triste vida,

para aumentar mis deseos

108 todos en el cielo habitan;

verme dellos apartada

es la pena más activa;

por aquel dulce amor tierno

112 que a ellos me tiene unida.

Aunque de cierto no sé

me veré en su compañía,

pero la fe y el amor

116 sincero el afecto aviva;

con los dos, que como alas

a lo superior subliman,

de la tierra me levanto

$120 \quad$ y voy donde el pecho anida.

Saludo a los cortesanos,

que el alto trono es su silla,

de caridad con abrazos

124 nuestra amistad se confirma.

¡Oh, dichosos amadores

del Dios, que a humano se inclina!, os ruego que le anunciéis

128 cómo mi alma está herida.

A mi Amado referid

mi deseo sin medida,

SCRIPTA, Revista internacional de literatura i cultura medieval i moderna, núm. 8 / desembre 2016 / pp. 194-223 
Verònica Zaragoza Gómez. Censura y edición póstuma de la obra de Hipólita de Rocabertí: a propósito de unos poemas manipulados

que está impaciente la pena

hasta este dichoso día;

con deseo deseado,

la muerte mis voces pidan,

que ella sola será el medio

de mi fortuna crecida;

otra cosa no deseo,

oh rey de gloria infinita,

sino verte do resides

en esa suprema silla.

Contenerme no es posible,

el amor me da gran prisa,

y son de poca eficacia

por más razones que diga.

Mi anhelo es poder cantar

con la música divina,

alabando a Dios eterno

mil cánticos de alegría;

mal podré, en destierro duro

en tierra ajena y cautiva,

entonar himnos de gozo,

de la tristeza oprimida,

a los celestiales coros

(oh cuánta les tengo invidia)

que en continuas aleluyas

su alegría testifican.

¡Oh, Jerusalén eterna!

¡Oh, visión de paz tranquila!

¿Cuándo saldré desta guerra

que el pecho turba y fatiga?

Yo me hallo con tristeza,

el cantar pide alegría

y solo el divino rostro

mis desalientos anima.

Si viese su cara hermosa

aun en esta vida indigna,

no sintiera sus trabajos

con tan celestes delicias.

Así que no quiero el cielo

por mi interés, que en la vista

de Dios y sus alabanzas

se cifra la gloría mía.

¡Oh, tres veces santo a quien

rey de ejércitos publican

los alados querubines,

mi alma admite que a ti aspira!

El cielo y tierra están llenos

de tu grandeza infinita,

pues que todo lo gobiernas,

hasta la vil sabandija. 
Verònica Zaragoza Gómez. Censura y edición póstuma de la obra de Hipólita de Rocabertí: a propósito de unos poemas manipulados

Testimonios

A AMA, ms. P2/15, s. p.

$v$ Tratado dividido... Valencia, Jaime Bordazar, 1683, pp. 520-525

A: Cantico que compuso la v.m sor Hipolita de jesus ÿ Rocaberti Religiosa del P.S. Domingo. En que trata del vivo dezeo que tenia de salir de la carcel del cuerpo mortal por no ofender ha su dulce amado Jesus y por gozar [...] con seguridad en su Reyno celestial»,

v: [SIN RÚBRICA]

«En que trata del vivo dezeo que tenia de salir de la carcel del cuerpo mortal por no ofender ha su dulce amado Jesus y por gozar [...] con seguridad en su Reyno celestial» $A$ : se añade en el margen izquierdo

2 apartada $A$ ] apartado $v 8$ amoroso $v]$ amrso $A 12$ propria $v]$ propia $A] 16$ incitan $A]$ inciten $v 18$ no $A$ ] es no $v$ 22 a amaros $A$ ] amaros $v 37$ apartada $A$ ] apartado $v 95$ dispuesta $A$ ] dispuesto $v 105$ vida $v$ ] vide $B 109$ apartada $A$ ] apartado $v 129$ referid $A$ ] le dezid $v$

Basamos la edición en A, que consideramos apógrafo. Corregimos con la impresión lo que parecen evidentes errores de copia en el manuscrito en los vv. 8 y 105.

[II]

«Aunque estoy cautiva en Babilonia

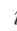

Aunque estoy cautiva en Babilonia, del pueblo de Judá tan apartada, de ti, Jerusalem, oh, ciudad santa,

4 de ti mi corazón nunca se aparta.

$\mathrm{Y}$, aunque sin sacrificio aquí se vive, mi alma encendida a Dios ofrezco y tres veces al día le hago entrega

8 de un puro corazón y mis deseos.

Y, aunque acá me honren, no lo estimo, solo el Dios de Israel es mi alegría, todo el buen trato que me hacen 12
Aunque cautivo estoy en Babilonia, del pueblo de Judá tan apartado, de ti, Jerusalén, oh, ciudad santa, no se apartan mis ojos y mi llanto.

Y, aunque sin sacrificio aquí se vive, mi alma ofrezco a Dios en holocausto y tres veces al día le hago entrega del corazón rendido y humillado.

Las honras que me ofrecen las desprecio, solo el Dios de Israel es mi descanso, atribuyendo a Él, en quien confío, 12 cuanta gloria me da el mundano aplauso. 
Verònica Zaragoza Gómez. Censura y edición póstuma de la obra de Hipólita de Rocabertí: a propósito de unos poemas manipulados

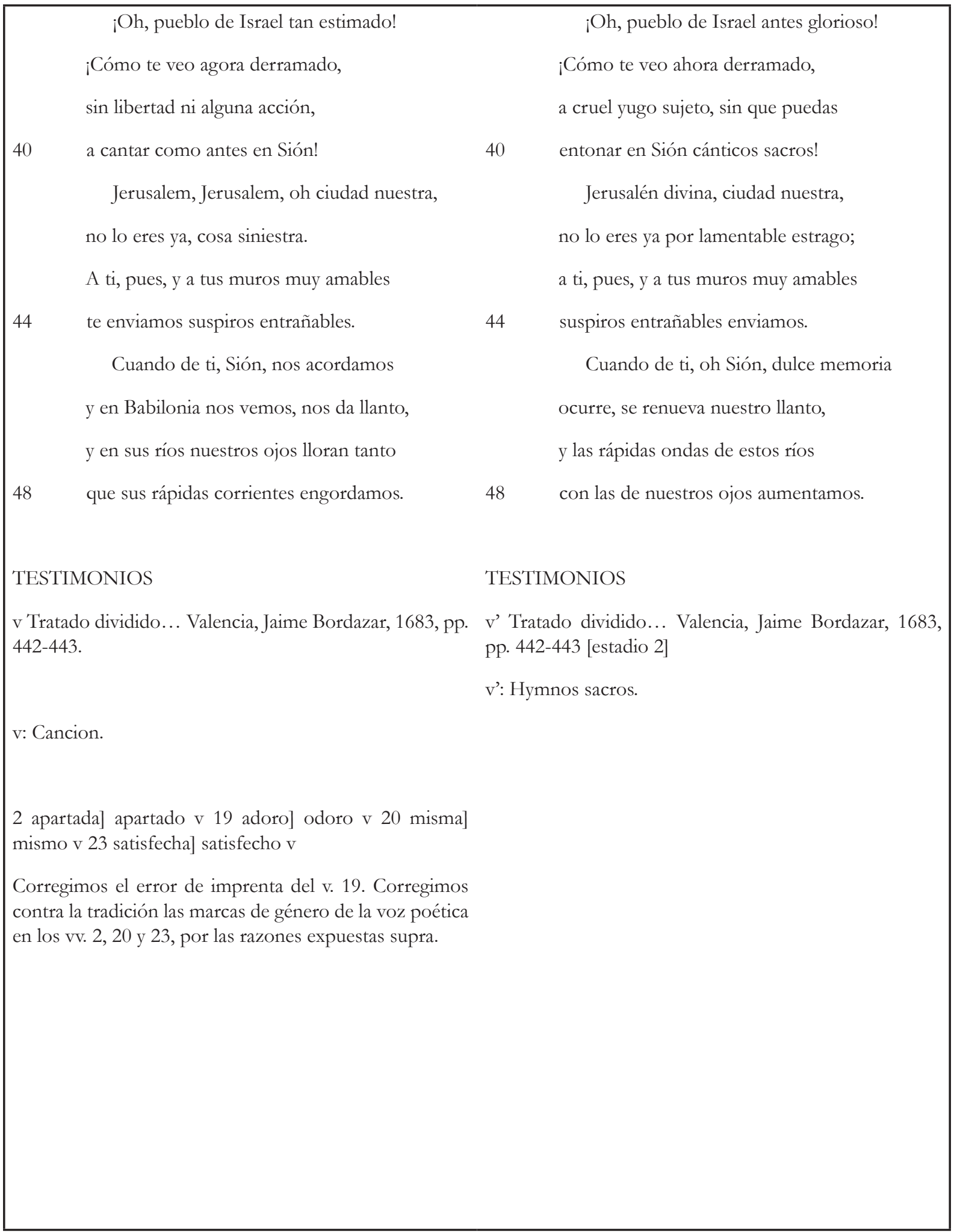


Verònica Zaragoza Gómez. Censura y edición póstuma de la obra de Hipólita de Rocabertí: a propósito de unos poemas manipulados

No me ocupo, pues, en estas cosas, que pasan como el viento sin firmeza; mi trato es con Dios, a quien adora mi alma por tantas que recibe gracias cada hora. 16

Hállole favorable en mis negocios, alabo sin cesar su santo nombre: Él solo es mi Dios y a Él adoro y me ofrezco a mí misma, por quien muero.

Toda mi voluntad le sacrifico, su magestad immensa le da vida $y$, aunque en destierro, estoy muy satisfecha por tener a Dios dentro mi pecho.

¡Oh, pueblo de Dios! ¿Qué ha sido esto, verte a otra nación estar sujeto? Pero, pues tus preceptos no guardamos, nosotros por pecar nos cautivamos: cautivos nos llevó a la tierra ajena, pagando lo merecido a nuestros yerros, pues somos el oprobio de las gentes: ¡Apiádate, Señor, destos vivientes!

Tu nombre invocamos y alabamos: no mires nuestras culpas; yo te ruego por tu amor, Señor, envíes luego
No me detengo, pues, en estas cosas, que huyen veloces, como el aire vago; es mi trato con Dios, a quien adoro y agradezco los bienes que me ha dado.

Hállole favorable en mis empresas; su santo nombre sin cesar alabo: Él es solo mi Dios y a Él venero y en su llama amorosa, fiel me abraso.

Toda mi voluntad le sacrifico, pues la vida recibo de su mano y, aunque en destierro, estoy muy satisfecho de que dentro de mí, su deidad guardo.

¡Oh, pueblo de mi Dios! Di: ¿Qué fortuna a otra nación cruel te ha sujetado? Pero, pues no guardamos tus preceptos, nosotros por pecar nos cautivamos, sujetos nos llevó a la tierra ajena la cadena infeliz de los pecados, y a ser el vil oprobrio de las gentes: ¡Ten piedad, oh Señor, pues te invocamos!

No mires nuestras culpas; yo te ruego con rendimiento humilde, a ti postrado, por tu amor, oh Señor, envíes luego el auxilio que tristes confiamos. 
Verònica Zaragoza Gómez. Censura y edición póstuma de la obra de Hipólita de Rocabertí: a propósito de unos poemas manipulados

[III]

«Haciendo el sacrificio vespertino»

$v$

Aunque estoy cautiva en Babilonia,

del pueblo de Judá tan apartada,

de ti, Jerusalem, oh, ciudad santa,

4 de ti mi corazón nunca se aparta.

$\mathrm{Y}$, aunque sin sacrificio aquí se vive,

mi alma encendida a Dios ofrezco

y tres veces al día le hago entrega

8 de un puro corazón y mis deseos.

Y, aunque acá me honren, no lo estimo,

solo el Dios de Israel es mi alegría,

todo el buen trato que me hacen

12 lo atribuyo a Dios en quien confío.

No me ocupo, pues, en estas cosas,

que pasan como el viento sin firmeza;

mi trato es con Dios, a quien adora

16

mi alma por tantas que recibe gracias cada hora. 16

Hállole favorable en mis negocios,

alabo sin cesar su santo nombre:

Él solo es mi Dios y a Él adoro

20 $v$

Aunque cautivo estoy en Babilonia,

del pueblo de Judá tan apartado,

de ti, Jerusalén, oh, ciudad santa,

4

no se apartan mis ojos y mi llanto.

$\mathrm{Y}$, aunque sin sacrificio aquí se vive, mi alma ofrezco a Dios en holocausto

y tres veces al día le hago entrega

8

del corazón rendido y humillado.

Las honras que me ofrecen las desprecio, solo el Dios de Israel es mi descanso, atribuyendo a Él, en quien confío, cuanta gloria me da el mundano aplauso.

No me detengo, pues, en estas cosas, que huyen veloces, como el aire vago; es mi trato con Dios, a quien adoro y agradezco los bienes que me ha dado.

Hállole favorable en mis empresas; su santo nombre sin cesar alabo:

Él es solo mi Dios y a Él venero 
Verònica Zaragoza Gómez. Censura y edición póstuma de la obra de Hipólita de Rocabertí: a propósito de unos poemas manipulados

Toda mi voluntad le sacrifico, su magestad immensa le da vida $y$, aunque en destierro, estoy muy satisfecha por tener a Dios dentro mi pecho. ¡Oh, pueblo de Dios! ¿Qué ha sido esto, verte a otra nación estar sujeto? Pero, pues tus preceptos no guardamos, nosotros por pecar nos cautivamos: cautivos nos llevó a la tierra ajena, pagando lo merecido a nuestros yerros, pues somos el oprobio de las gentes: ¡Apiádate, Señor, destos vivientes! Tu nombre invocamos y alabamos: no mires nuestras culpas; yo te ruego por tu amor, Señor, envíes luego el auxilio que de ti tristes confiamos. ¡Oh, pueblo de Israel tan estimado! ¡Cómo te veo agora derramado, sin libertad ni alguna acción, a cantar como antes en Sión! Jerusalem, Jerusalem, oh ciudad nuestra, no lo eres ya, cosa siniestra. A ti, pues, y a tus muros muy amables
Toda mi voluntad le sacrifico, pues la vida recibo de su mano y, aunque en destierro, estoy muy satisfecho de que dentro de mí, su deidad guardo. ¡Oh, pueblo de mi Dios! Di: ¿Qué fortuna a otra nación cruel te ha sujetado? Pero, pues no guardamos tus preceptos, nosotros por pecar nos cautivamos, sujetos nos llevó a la tierra ajena la cadena infeliz de los pecados, y a ser el vil oprobrio de las gentes: ¡Ten piedad, oh Señor, pues te invocamos! No mires nuestras culpas; yo te ruego con rendimiento humilde, a ti postrado, por tu amor, oh Señor, envíes luego el auxilio que tristes confiamos. ¡Oh, pueblo de Israel antes glorioso! ¡Cómo te veo ahora derramado, a cruel yugo sujeto, sin que puedas entonar en Sión cánticos sacros! Jerusalén divina, ciudad nuestra, no lo eres ya por lamentable estrago; a ti, pues, y a tus muros muy amables suspiros entrañables enviamos. 
Verònica Zaragoza Gómez. Censura y edición póstuma de la obra de Hipólita de Rocabertí: a propósito de unos poemas manipulados

Cuando de ti, Sión, nos acordamos

y en Babilonia nos vemos, nos da llanto,

y en sus ríos nuestros ojos lloran tanto

48 que sus rápidas corrientes engordamos.

\section{TESTIMONIOS}

v Tratado dividido... Valencia, Jaime Bordazar, 1683, pp. 442-443.

v: Cancion.

2 apartada] apartado v 19 adoro] odoro v 20 misma] mismo v 23 satisfecha] satisfecho v

Corregimos el error de imprenta del v. 19. Corregimos contra la tradición las marcas de género de la voz poética en los vv. 2, 20 y 23, por las razones expuestas supra.
Cuando de ti, oh Sión, dulce memoria

ocurre, se renueva nuestro llanto,

y las rápidas ondas de estos ríos

48 con las de nuestros ojos aumentamos.

\section{TESTIMONIOS}

v' Tratado dividido... Valencia, Jaime Bordazar, 1683, pp. 442-443 [estadio 2]

v': Hymnos sacros. 
Verònica Zaragoza Gómez. Censura y edición póstuma de la obra de Hipólita de Rocabertí: a propósito de unos poemas manipulados

\section{Bibliografía}

Ahumada, E. (2013) «Hipólita de Jesús. Biografía y bibliografía», en La vida cotidiana y sociabilidad de los dominicos, coord. Rosa María Alabrús Iglesias, San Cugat, Editorial Arpegio, 133-148.

—. (2011) «La carta privada a l'època moderna: un epistolari conventual femení inèdit», Manuscrits, 29 [=Les pràctiques epistolars (segles XVI-XIX)], 51-64.

——. (2013)«Hipólita de Jesús. Biografía y Bibliografía», en R.M. Alabrús (ed.), La vida cotidiana y la sociabilidad de los dominicos, Sant Cugat: Arpegio, 133-148.

Alabrús, R.M. (2015a) «La espiritualidad de Hipólita de Rocabertí y la construcción de su imagen en el siglo XVII», Hispania Sacra, 67 /135, 219-245

—_. (2015b): «Visiones y sueños de las monjas del barroco español», e-Spania, 21 (juny) [en línia: https://e-spania.revues.org/24474] [consulta: 10/09/2016].

Baranda, N. (2013) «Producción y consumo poéticos en los conventos femeninos», Bulletin Hispanique, 115 /1, 165-184.

Baranda, N. \& Marín, M.C. (2014) «El universo de la escritura conventual femenina: deslindes y perspectivas», en N. Baranda \& M.C. Marín (ed.), Letras en la celda. Cultura escrita de los conventos femeninos en la España moderna, Madrid/Frankfurt, Iberoamericana/Vervuert (Tiempo Emulado. Historia de América y España, 32), 11-45.

Callado Estela, E. (2007) Por Dios y por el rey: el inquisidor general fray Juan Tomás de Rocabertí, Valencia, Institució Alfons el Magnànim.

- (2012) «Historia y glorias dominicanas en la obra editorial de fray Juan Tomás de Rocabertí», en Rosa María Alabrús Iglesias (coord.), La memoria escrita de los dominicos, San Cugat, Editorial Arpegio, 59-85.

Díaz Rengifo, J. [1759] Arte poética española: con una fertilíssima sylva de consonantes comunes, propios, esdrúxulos y reflexos, y un divino estímulo del amor de Dios [...] aumentada en esta uiltima impressión con dos tratados, uno de avisos y reglas, otro de asonantes, Barcelona, Maria Ángela Martí, víuda.

Giordano, M. L. (2011) «La Contrarreforma y sus críticos. Biblia y oración mental en Hipólita de Rocabertí» en Rosa María Alabrús Iglesias (coord.), Tradición y modernidad. El pensamiento de los dominicos en la Corona de Aragón en los siglos XVII y XVIII, Madrid, Sílex, 17-52.

- (2012a) «Memoria y tradición en la dominica catalana Hipólita de Jesús», en Rosa María Alabrús Iglesias (coord.), La memoria escrita de los dominicos, San Cugat, Editorial Arpegio, 177-198.

—. (2012b) «Dos caras de la contrarreforma: Juan de Ribera y sor Hipólita de Jesús», dins E. Callado (ed.), El Patriarca Ribera y su tiempo. Religión, cultura y política en la Edad Moderna, Valencia, Alfons el Magnànim, 201-213.

. (2013) «I "salici sterili” della religione esteriore. Sor Hipólita de Jesús e la Controriforma (1551-1699)», Quaderni Storici, 48/144, 2013, 857-888.

SCRIPTA, Revista internacional de literatura i cultura medieval i moderna, núm. 8 / desembre 2016 / pp. 194-223 ISSN: 2340-4841 · doi:10.7203/SCRIPTA.8.9295 
Verònica Zaragoza Gómez. Censura y edición póstuma de la obra de Hipólita de Rocabertí: a propósito de unos poemas manipulados

Jiménez Faro, Luz M. (ed. 1996) Poetisas españolas. Antología general. Tomo I: Hasta 1900, Madrid: Torremozas.

Lavrin, A. (2014) «Erudición, devoción y creatividad tras las rejas conventuales», en N. Baranda Leturio \& M.C. Marín Pina, (ed.), Cultura escrita de los conventos femeninos en la España moderna, Madrid/Frankfurt, Iberoamericana / Vervuert (Tiempo Emulado. Historia de América y España, 32), 65-88.

Lorea, A. (1679), La venerable Madre Hipólita de Jesús y Rocabertí, religiosa de la orden de N. P. S. Domingo en el monasterio de Nuestra Señora de los Ángeles de la ciudad de Barcelona. Epitome de su prodigiosa vida, virtudes y admirables escritos, sacado de los procesos de su beatificación y canonización, y otros instrumentos auténticos, compuesto por el maestro fray Antonio de Lorea, de la misma orden y su coronista, dedicado a Iesu Christo Dios, y hombre, verdadero, nuestro redentor, Valencia, Vicente Cabrera.

Malena, A. (2003) L'eresia dei perfetti. Inquisizione Romana ed esperienze mistiche nel Seicento italiano, Rome, Edizioni di Storia e Letteratura (Temi e Testi, 47).

Moll, J. (1979) «Problemas bibliográficos del libro del Siglo de Oro», Separata de: Boletín de la Real Academia Española, 59/216 (enero-abril) Madrid, Imprenta Aguirre, 49-107.

Morujão, I. (1996) «Poesia e Santidade: alguns contributos para uma percepção do conceito de santidade, a partir de duas biografias devotas de religiosas do séc. XVIII português», Via Spiritus, $3,235-261$.

Núñez, V. (2005) «La poesía religiosa del Siglo de Oro. Historia, transmisión y canon», en Begoña López Bueno (dir.), En torno al canon: aproximaciones y estrategias, Sevilla, Grupo PASO, Universidad de Sevilla, 333-370.

Peña, M. (1999) «Manipulación masculina del discurso femenino en biografías de monjas», en M. Bosse, B. Potthast \& A. Stoll (ed.), La creatividad femenina en el mundo barroco hispánico, vol. II, Kassel: Reichenberger, 597-610.

Pérez Samper, M.A. (2014) «Las Virreinas: mujeres y poder en la Cataluña de los Austrias», en Gloria Angeles Franco Rubio \& María de los Ángeles Pérez Samper (coord.), Herederas de Clío. Mujeres que han impulsado la historia. Homenaje a $M^{a}$ Victoria López-Cordón Cortezo, Sevilla, Mergablum, 431 450.

Poutrin, I. (1995) Le voile et la plume. Autobiographie et sainteté féminine dans l'Espagne moderne, Madrid, Casa de Velázquez.

- (2015) «Censuras y elogios. Los paratextos de las obras de sor Hipólita de Jesús (16791683)», Criticón, 125, 107-119.

Rocabertí, H. (1679) La venerable madre Hipólita de Jesús y Rocabertí. Libro primero de su admirable vida y dotrina, que escrivió de su mano por mandato de sus prelados y confessores..., Valencia, Francisco Mestre.

(1680) Tomo tercero. De la Penitencia, temor de Dios y Meditaciones celestiales [...], Valencia, Francisco Mestre.

SCRIPTA, Revista internacional de literatura i cultura medieval i moderna, núm. 8 / desembre 2016 / pp. 194-223 
Verònica Zaragoza Gómez. Censura y edición póstuma de la obra de Hipólita de Rocabertí: a propósito de unos poemas manipulados

- (1683) Tratado dividido en quatro libros. El primero contiene: la exposición literaly mística de los psalmos penitenciales; el segundo, la preparación para la muerte; el tercero, coloquios del alma christiana con Dios; el quarto, fundamento sólido de la oración por ser todo fundado en el santo Evangelio..., Valencia, Jaime Bordázar.

- (1684) Libro segundo Mýstica exposición de la Salve Regina que por mandado de sus prelados y confessores dexó escrita de su mano la venerable madre Hipólita de Jesús y Rocabertí..., Valencia, Manuel Gómez.

. (1685) La venerable madre Hipólita de Jesús y Rocabertí. Libro primero de su admirable vida y dotrina, que escrivió de su mano por mandato de sus prelados y confessores..., Valencia, Francisco Mestre.

—. (1685) Libro tercero de la vida, que por mandado de sus prelados, y confessores, dexó escrita de su mano la venerable madre Hipólita de Jesús y Rocabertí...,Valencia, Vicent Cabrera.

- (1685) Libro segundo Mýstica exposición de la Salve Regina que por mandado de sus prelados y confessores dexó escrita de su mano la venerable madre Hipólita de Jesús y Rocabertí..., Valencia, Francisco Mestre.

Rocabertí, H. (1694) Exposición literal, mýstica y moral sobre los lugares más selectos de los SS. Quatro Evangelios, sacada de las obras de la venerable madre Hipólita de Iesúsy Rocabertí, de la orden de predicadores..., Valencia, Jaime Bordázar.

Serrano y Sanz, M. (1903-1905 [1975]) Apuntes para una Biblioteca de Escritoras Españolas desde 1401 a 1833, 2 vol., Madrid: Biblioteca Nacional [Reimp. Madrid: Atlas].

Serrano y Sanz, M. (1915) Antología de poetisas líricas, 2 vol., Madrid: RAE.

Zaragoza, V. (2013) «Historiar les protagonistes absents. La poesia femenina de l'edat moderna a l'àmbit català», en L. Josa \& M. Lambea (ed.), 'Allegro con brio'. I Encuentro "Aula Música Poética" de Jóvenes Humanistas. (Barcelona, 9 y 10 de octubre de 2012), Digital CSIC, 146-159.

. (2012 [2015]): «La obra literaria de los Fontanella al entorno del monasterio dominico de Nuestra Señora de los Ángeles y Pie de la Cruz (Barcelona, siglo XVII)», Archivum Fratrum Praedicatorum, LXXXII, 217-267.

. (2016), «En vers vull desafiar...». La poesia femenina a l'àmbit català (segles ХИ-ХИІІІ), Edició crítica, 2 vol., Tesis Doctoral inédita. Universitat de Girona. Dirigida por Pep Valsalobre. 